\title{
One-year follow-up of femtosecond laser-assisted penetrating keratoplasty
}

\author{
Johnson Choon-Hwai Tan \\ Wee-Jin Heng \\ National Healthcare Group Eye \\ Institute, Tan Tock Seng Hospital, \\ Singapore
}

This article was published in the following Dove Press journal:

Clinical Ophthalmology

23 February 2013

Number of times this article has been viewed

Background: The purpose of this report is to describe the initial outcomes of femtosecond laser-assisted penetrating keratoplasty.

Methods: This retrospective surgical case series consisted of 10 eyes from 10 patients undergoing penetrating keratoplasty at a tertiary center. Femtosecond laser was used to perform a zig-square incision on the donor cornea with matched dimensions on the recipient cornea. Outcomes measured included: unaided visual acuity and best spectacle-corrected visual acuity preoperatively and at one, 3, 6, and 12 months postoperatively; manifest refractive and topographic astigmatism at 3, 6, and 12 months postoperatively; and endothelial cell density loss, calculated at the end of the one-year follow-up period.

Results: At one-year follow-up, there was an improvement in unaided visual acuity from a mean preoperative logMAR of 1.67 to 0.44 , and best spectacle-corrected visual acuity from a mean preoperative $\log$ MAR of 1.33 to 0.13 . By postoperative month 3, mean manifest refractive and topographic astigmatism was $2.31 \pm 1.41 \mathrm{D}$ and $2.59 \pm 1.57 \mathrm{D}$, respectively. The mean reduction in endothelial cell density was $20.7 \%$ after one year of follow-up.

Conclusion: Femtosecond laser-assisted penetrating keratoplasty provided a good visual outcome and early visual rehabilitation due to precise graft-host alignment and reduced astigmatism in the early postoperative months.

Keywords: penetrating keratoplasty, femtosecond laser-assisted keratoplasty

\section{Introduction}

Corneal transplantation is one of the oldest and most successful transplant procedures when compared with other types of solid organ transplantation. However, surgical manipulation during traditional penetrating keratoplasty results in significant astigmatism from uneven graft-host alignment, torsional misalignment, uneven trephination, and uneven suture tension. ${ }^{1} \mathrm{~A}$ vertical edge-to-edge cut at the graft-host junction also requires tighter sutures to withstand the effects of intraocular pressure and any external pressure, and also risks wound dehiscence after suture removal.

Barraquer and Rutllan ${ }^{2}$ introduced the top-hat configuration of penetrating keratoplasty in 1964, and in 2003, Busin ${ }^{3}$ reported a series of eight eyes with stepped lamellar configuration for penetrating keratoplasty. The larger wound surface area probably conferred greater wound strength, thereby allowing earlier suture removal and more rapid visual rehabilitation. However, the surgery was technically very demanding due to limitations in instrumentation at that time, and so was largely abandoned.

In 2006, Ignacio et $\mathrm{al}^{4}$ used the femtosecond laser in cadaveric eyes to create a "tophat" penetrating keratoplasty, and showed that such a configuration could withstand

Tan

National Healthcare Group Eye Institute,

Tan Tock Seng Hospital, I I Jalan Tan

Tock Seng, Singapore 308433

Tel +6563577726

Fax +65 63577718

Email johnsontch@gmail.com 
a greater increase in intraocular pressure than could a traditional penetrating keratoplasty. This was further supported by Bahar et al, ${ }^{5}$ who demonstrated that top-hat penetrating keratoplasty could resist higher burst pressure than the traditional vertical edge, mushroom, zig-zag, or Christmas tree configuration. Steinert et $\mathrm{al}^{6}$ reported similar results with top-hat penetrating keratoplasty, and complete suture removal as early as postoperative month 3 permitted rapid visual rehabilitation. Use of radial alignment incisions with the femtosecond laser minimized horizontal torsion induced by asymmetrical suture placement, and hence improved postoperative astigmatism in a study by Kook et al. ${ }^{7}$ A larger transplant endothelial cell population could also be achieved with a larger transplanted endothelial surface in the top-hat configuration.

This paper reports the outcomes for 10 eyes that underwent femtosecond laser-assisted penetrating keratoplasty (FLPK) at our center.

\section{Materials and methods \\ Patients}

A retrospective chart review of 10 eyes from 10 patients requiring penetrating keratoplasty was carried out. All procedures were performed between October 2009 and August 2011 by a single surgeon at the National Healthcare Group Eye Institute, Tan Tock Seng Hospital, Singapore. Institutional review board approval and informed consents were obtained. The study adhered to the tenets of the Declaration of Helsinki.

Preoperatively, a complete ophthalmic examination was performed, including unaided visual acuity and best spectacle-corrected visual acuity measured in logarithm of minimal angle of resolution ( $\log$ MAR) units, slit-lamp biomicroscopy, tonometry, and dilated fundus examination. Corneal topography (Orbscan $\mathrm{IIz}^{\circledR}$, Bausch and Lomb, Rochester, NY, USA) and endothelial cell density (Noncon Specular Microscope $\mathrm{V}^{\circledR}$, Konan Medical USA Inc, Irvine, CA, USA) were also measured in all eyes. Corneal thickness at eight points in the $7 \mathrm{~mm}$ to $8 \mathrm{~mm}$ diameter zone was measured with ultrasound (Pachmate DGH 55, DGH Technology Inc, Exton, PA, USA) and Orbscan pachymetry to determine the corneal thickness at the thinnest point along the zone.

\section{Surgical technique}

Donor trephination was carried out before recipient trephination. The donor cornea was mounted in an artificial anterior chamber (NetWork Medical Products, Ripon, UK; Barron Precision Instruments Inc, Grand Blanc Township, MI, USA) with ophthalmic viscoelastic device coating of the endothelial surface.
An incision was made on the donor cornea using a $60 \mathrm{kHz}$ or $150 \mathrm{kHz}$ femtosecond laser (IntraLase ${ }^{\mathrm{TM}} \mathrm{FS}$ Laser, Abbott Medical Optics Inc, Abbott Park, IL) with a zig-square shape pattern. For the donor cornea, the posterior side cut was programmed to be penetrating, and to end $30 \mu \mathrm{m}$ anterior to the lamellar resection plane. The lamellar resection was set at a depth of $300 \mu \mathrm{m}$ and extended $30 \mu \mathrm{m}$ outside the posterior side cut. The anterior side cut was angled at 40 degrees to the anterior corneal surface, and similarly had an overlap of $30 \mu \mathrm{m}$ with the lamellar resection (Figure 1). The anterior diameter ranged from $7.3 \mathrm{~mm}$ to $7.5 \mathrm{~mm}$, and the posterior diameter ranged from $7.6 \mathrm{~mm}$ to $7.8 \mathrm{~mm}$ (Table 1).

The laser-trephined donor cornea button was then placed endothelium side up with ophthalmic viscoelastic device coating, and transported to the operating room bathed in Optisol (Chiron Ophthalmics, Irvine, CA, USA).

The incision on the recipient's cornea was made with a suction ring applied to the eye, using the same laser settings and dimensions as the donor cornea, except that the depth of the posterior side cut was programmed to begin $70 \mu \mathrm{m}$ anterior to the endothelium at the thinnest point measured to obtain a nonpenetrating cut.

In the operating room, any adhesions along the cut surfaces of the recipient's cornea were dissected with a Sinskey hook, and the residual posterior stroma was cut with corneal scissors. The recipient cornea was excised, and the donor cornea was sutured in place with four cardinal 10-0 nylon sutures, followed by a 16-bite single continuous $10-0$ nylon suture or 16 interrupted 10-0 nylon sutures.

\section{Data collection}

In the postoperative period, unaided visual acuity and best spectacle-corrected visual acuity were recorded at the end of the first month and subsequently at months 3,6 , and 12 . The amount of astigmatism was determined from manifest refraction and corneal topography (Sim K values) at months 3, 6, and 12 postoperatively, and endothelial cell density was measured at the postoperative month 12 visit. Anterior segment optical coherence tomography (OCT, iVue ${ }^{\circledR}$, Optovue Inc, Fremont, CA, USA; Visante ${ }^{\circledR}$ OCT, Carl Zeiss AG, Oberkochen, Germany) was also used to study the donor-recipient wound profile.

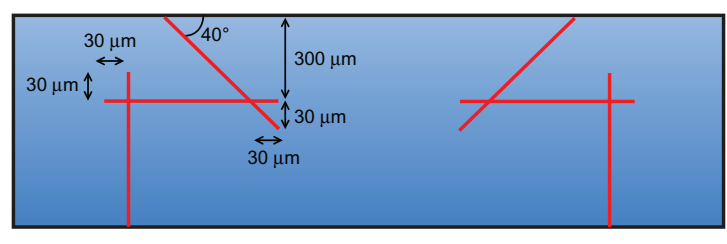

Figure I Side profile of zig-square wound created by the femtosecond laser. 
Table I Subject demographics, incisions dimensions and suturing technique

\begin{tabular}{|c|c|c|c|c|c|c|c|c|}
\hline $\begin{array}{l}\text { Patient } \\
\text { number }\end{array}$ & $\begin{array}{l}\text { Age } \\
\text { (years) }\end{array}$ & Gender & Diagnosis & $\begin{array}{l}\text { Combined } \\
\text { procedure }\end{array}$ & $\begin{array}{l}\text { Eye } \\
\text { treated }\end{array}$ & $\begin{array}{l}\text { Donor posterior } \\
\text { diameter }(\mathrm{mm})\end{array}$ & $\begin{array}{l}\text { Recipient posterior } \\
\text { diameter }(\mathrm{mm})\end{array}$ & $\begin{array}{l}\text { Suturing } \\
\text { technique }\end{array}$ \\
\hline 1 & 56 & Female & Lattice dystrophy & $\mathrm{Nil}$ & Left & 7.8 & 7.8 & 16 interrupted \\
\hline 2 & 76 & Female & $\begin{array}{l}\text { Pseudophakic } \\
\text { bullous keratopathy }\end{array}$ & Nil & Left & 7.7 & 7.7 & Continuous \\
\hline 3 & 76 & Male & $\begin{array}{l}\text { Pseudophakic } \\
\text { bullous keratopathy }\end{array}$ & Nil & Left & 7.7 & 7.7 & Continuous \\
\hline 4 & 75 & Female & $\begin{array}{l}\text { Pseudophakic } \\
\text { bullous keratopathy }\end{array}$ & $\mathrm{Nil}$ & Left & 7.7 & 7.7 & Continuous \\
\hline 5 & 63 & Male & Chemical injury & CE-IOL & Left & 7.7 & 7.7 & 16 interrupted \\
\hline 6 & 67 & Male & $\begin{array}{l}\text { Pseudophakic } \\
\text { bullous keratopathy }\end{array}$ & Nil & Left & 7.9 & 7.9 & 16 interrupted \\
\hline 7 & 55 & Male & $\begin{array}{l}\text { Pseudophakic } \\
\text { bullous keratopathy }\end{array}$ & $\mathrm{Nil}$ & Right & 7.7 & 7.7 & 16 interrupted \\
\hline 8 & 72 & Female & $\begin{array}{l}\text { Fuch's endothelial } \\
\text { dystrophy }\end{array}$ & CE-IOL & Left & 7.9 & 7.9 & Continuous \\
\hline 9 & 69 & Female & $\begin{array}{l}\text { LPI-induced } \\
\text { bullous keratopathy }\end{array}$ & CE-IOL & Right & 7.7 & 7.7 & Continuous \\
\hline 10 & 72 & Female & $\begin{array}{l}\text { Fuch's endothelial } \\
\text { dystrophy }\end{array}$ & CE-IOL & Left & 7.6 & 7.6 & Continuous \\
\hline
\end{tabular}

Abbreviations: CE-IOL, cataract extraction with implantation of the intraocular lens; LPI, laser peripheral iridotomy.

\section{Results}

The patients comprised four men and six women of mean age 68 (range 55-76) years who had undergone uneventful FLPK. The most common indication was pseudophakic bullous keratopathy (five eyes) followed by Fuch's endothelial dystrophy (two eyes). One eye had laser peripheral iridotomyinduced bullous keratopathy, one had lattice dystrophy, and another had a corneal scar from previous chemical injury. Four eyes also had cataract extraction and intraocular lens implantation at the time of FLPK (Table 1).

Preoperatively, mean unaided visual acuity was $\log$ MAR 1.67 and mean best spectacle-corrected visual acuity was $\log$ MAR 1.33 (Table 2). By postoperative month 3, unaided visual acuity and best spectacle-corrected visual acuity were at least $\log$ MAR 0.7 and $\log$ MAR 0.3 , respectively, for all patients except patient 4 . One year after surgery, mean unaided visual acuity was $\operatorname{logMAR} 0.44$ and mean best spectacle-corrected visual acuity was $\log$ MAR 0.13 . There was a mean improvement of $\log$ MAR 1.23 in unaided visual acuity and of logMAR 1.20 in best spectacle-corrected visual acuity over the one-year follow-up period. Patient 4 had a preexisting epiretinal membrane, and had undergone membrane peeling surgery 9 months after FLPK. However, her vision remained poor because of macular pathology. Her unaided visual acuity and best spectacle-corrected visual acuity were thus not included in the above analysis.

At postoperative month 3, except for patient 1 who had a high cylinder of 12 diopters (D), all patients had manifest refractive and topographic cylinders of less than $4 \mathrm{D}$ and $5 \mathrm{D}$ (Table 3), with respective means of $2.31 \pm 1.41 \mathrm{D}$ and

Table 2 Visual acuity preoperatively and at postoperative month 12

\begin{tabular}{|c|c|c|c|c|c|c|c|c|c|c|}
\hline \multirow{2}{*}{$\begin{array}{l}\text { Patient } \\
\text { number }\end{array}$} & \multicolumn{2}{|c|}{ Preoperative } & \multicolumn{2}{|c|}{ I month } & \multicolumn{2}{|c|}{3 months } & \multicolumn{2}{|c|}{6 months } & \multicolumn{2}{|c|}{12 months } \\
\hline & UAVA & BSCVA & UAVA & BSCVA & UAVA & BSCVA & UAVA & BSCVA & UAVA & BSCVA \\
\hline I & I & I & 0.7 & 0.6 & 0.4 & 0.2 & 0.5 & 0.3 & 0.3 & 0.2 \\
\hline 2 & 1.3 & 0.7 & 0.6 & 0.4 & 0.7 & 0.3 & 0.1 & 0 & 0.1 & 0 \\
\hline 3 & 2 & 1.3 & 0.5 & 0.4 & 0.6 & 0.3 & 0.9 & 0.4 & 0.7 & 0.3 \\
\hline 4 & 2 & 2 & 2 & 1.3 & 2 & 0.9 & 2 & 2 & 2 & 2 \\
\hline 5 & 2 & 2 & 0.7 & 0.5 & 0.5 & 0.3 & 0.5 & 0.2 & 0.5 & 0 \\
\hline 6 & 2 & 2 & 0.7 & 0.4 & 0.6 & 0.2 & 0.8 & 0.1 & 0.5 & 0.1 \\
\hline 7 & 2 & 2 & 0.4 & 0.3 & 0.4 & 0.2 & 0.4 & 0 & 0.5 & 0.2 \\
\hline 8 & 0.7 & 0.4 & 0.5 & 0.4 & 0.7 & 0.3 & 0.7 & 0.3 & 0.3 & 0.1 \\
\hline 9 & 2 & 2 & 0.6 & 0.3 & 0.7 & 0.1 & 0.8 & 0 & 0.8 & 0.1 \\
\hline 10 & 2 & 0.6 & 0.7 & 0.3 & 0.4 & 0.2 & 0.5 & 0.2 & 0.3 & 0.2 \\
\hline
\end{tabular}

Abbreviations: BSCVA, best spectacle-corrected visual acuity; UAVA, unaided visual acuity. 
Table 3 Manifest and Sim K astigmatism preoperatively and at postoperative month 12

\begin{tabular}{|c|c|c|c|c|c|c|}
\hline \multirow{2}{*}{$\begin{array}{l}\text { Patient } \\
\text { number }\end{array}$} & \multicolumn{2}{|c|}{3 months } & \multicolumn{2}{|c|}{6 months } & \multicolumn{2}{|c|}{12 months } \\
\hline & $\begin{array}{l}\text { MC } \\
\text { (D) }\end{array}$ & $\begin{array}{l}\text { Sim K* } \\
\text { (D) }\end{array}$ & $\begin{array}{l}\text { MC } \\
\text { (D) }\end{array}$ & $\begin{array}{l}\operatorname{Sim} K \\
\text { (D) }\end{array}$ & $\begin{array}{l}\text { MC } \\
\text { (D) }\end{array}$ & $\begin{array}{l}\text { Sim K } \\
\text { (D) }\end{array}$ \\
\hline I & 12 & 12.1 & 6 & 4.1 & 3 & 4.7 \\
\hline 2 & 3 & 2.7 & 2.5 & 3.4 & 2.5 & 4.7 \\
\hline 3 & 3.5 & 3.6 & 2.5 & 2.4 & 2.5 & 2.8 \\
\hline 4 & 4 & 5 & 4 & 4.1 & 5 & 3.8 \\
\hline 5 & 0.5 & 2.5 & 0.5 & I.I & 1.75 & 2.6 \\
\hline 6 & 2 & 2.4 & 2.5 & 1.8 & 2.75 & 3.6 \\
\hline 7 & 4 & 4.2 & 4 & 3.2 & 4.25 & 3.2 \\
\hline 8 & 2.3 & 2.2 & 3.3 & 7.1 & 1 & 5 \\
\hline 9 & 0.5 & 0.4 & 0.8 & 1.2 & 2 & 2.6 \\
\hline 10 & I & 0.3 & 0 & 0.6 & 0.75 & 2.2 \\
\hline
\end{tabular}

Note: $*$ Sim K astigmatism.

Abbreviations: $M C$, manifest cylinder; $D$, diopters.

$2.59 \pm 1.57 \mathrm{D}$ (excluding patient 1$)$. Selective removal of sutures was only performed from postoperative month 4 onwards in all patients. At one-year follow-up, the mean manifest refractive and topographic cylinders of the 10 eyes were $2.55 \pm 1.32 \mathrm{D}$ and $3.52 \pm 1.01 \mathrm{D}$, with eight eyes having manifest cylinder of $3 \mathrm{D}$ or less, and seven eyes having topographic cylinder of less than $4 \mathrm{D}$. There was no statistically significant difference between mean manifest refractive cylinder at 3 months and at one year $(P=0.70)$, and similarly so for topographic cylinder $(P=0.15)$. The manifest refractive and topographic cylinder in patient 1 had decreased to $3 \mathrm{D}$ and $4.7 \mathrm{D}$, respectively, by one year. Patient 8 developed suture infiltrates and vascularization that caused her astigmatism to increase. Adjustment of suture tension was performed at postoperative months 4 and 8 . By the end of one-year follow-up, her manifest astigmatism had decreased to $1 \mathrm{D}$.

Mean preoperative endothelial cell density was 2945 (range 2518-3412) cells $/ \mathrm{mm}^{2}$. At the end of the one-year follow-up period, the mean endothelial cell density was 2382 (range 2036-2857) cells $/ \mathrm{mm}^{2}$ with a $20.7 \%$ mean reduction in endothelial cell density (Table 4).

The wound profile after FLPK was demonstrated using Optovue OCT (Figure 2). At one-year follow-up, a smooth contour of the anterior corneal surface with good adhesion along the interface of the wound could be seen. The zig-square wound profile had been successfully achieved as planned. This was similarly demonstrated in Figure 3, which showed the OCT wound profile of patient 9 at the month 6 follow-up visit. The smooth edges of the interface cut by femtosecond laser are demonstrated on histological sectioning (Figure 4).
Table 4 Endothelial cell density preoperatively and at postoperative month 12

\begin{tabular}{llll}
\hline $\begin{array}{l}\text { Patient } \\
\text { number }\end{array}$ & $\begin{array}{l}\text { Preop ECD } \\
\left.\text { (cells } / \mathbf{m m}^{2}\right)\end{array}$ & $\begin{array}{l}\text { I } \mathbf{\text { months ECD }} \\
\text { (cells } / \mathbf{m m}^{2} \text { ) }\end{array}$ & $\begin{array}{l}\text { ECD } \\
\text { loss }(\%)\end{array}$ \\
\hline 1 & 2906 & 2036 & 30 \\
2 & 3412 & 2564 & 25 \\
3 & 2518 & 2108 & 16 \\
4 & 3300 & 2857 & 13 \\
5 & 2800 & 2224 & 21 \\
6 & 2747 & 2217 & 19 \\
7 & 2701 & 2208 & 18 \\
8 & 3401 & 2567 & 25 \\
9 & 2597 & 2083 & 20 \\
10 & 3067 & 2475 & 19 \\
& & Mean & 20.7 \\
\hline
\end{tabular}

Abbreviation: Preop ECD, preoperative endothelial cell density.

Patient 6 developed glaucoma after FLPK, and subsequently required trabeculectomy with application of mitomycin C. Subsequently, there was good intraocular pressure control without antiglaucoma medication. There were no cases of rejection or other complications during the one-year follow-up.

\section{Discussion}

Although trephination with vacuum trephines has greatly improved the outcome of penetrating keratoplasty, there are still many imperfections, including graft decentration,

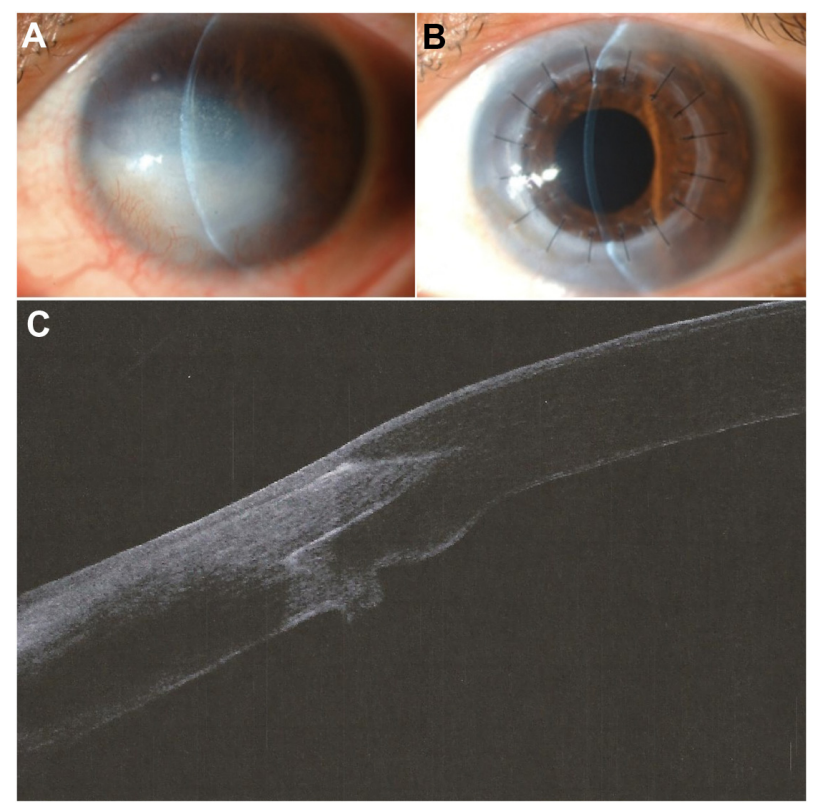

Figure 2 Photographs and Optovue ${ }^{\circledR}$ anterior segment optical coherence tomographic image from patient 5. (A) Preoperative photograph. (B) Postoperative photograph at week 8. (C) One year after femtosecond laser-assisted penetrating keratoplasty, there was a smooth anterior surface and good wound healing and apposition of the interlocking zig-square configuration. 


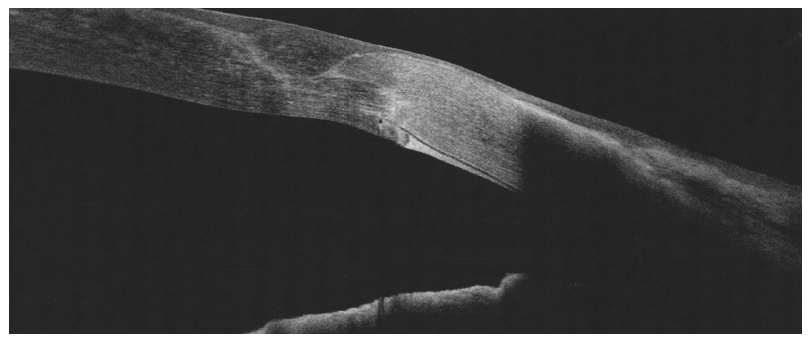

Figure 3 Optovue ${ }^{\circledR}$ anterior segment optical coherence tomographic image of patient 9 at 6 months after femtosecond laser-assisted penetrating keratoplasty, showing a well apposed donor-recipient junction with the zig-square incision.

mismatch in graft-host sizing, wound apposition misalignment, astigmatism resulting from unequal suture tension, and a higher risk of wound dehiscence. Therefore, patients usually undergo a long period of visual rehabilitation due to astigmatism and wound healing.

While lamellar keratoplasty has replaced penetrating keratoplasty for many indications today, there are still a significant number of corneal diseases that will require penetrating keratoplasty, such as advanced bullous keratopathy with significant stromal scarring, keratoconus with previous hydrops resulting in full-thickness corneal scarring, and deep corneal scarring down to the level of Descemet's membrane. Therefore, it is necessary to explore how penetrating keratoplasty techniques can be improved further to produce visual results that can approximate that of Descemet's stripping automated endothelial keratoplasty or Descemet's membrane endothelial keratoplasty for patients in whom penetrating keratoplasty is the only appropriate treatment modality.

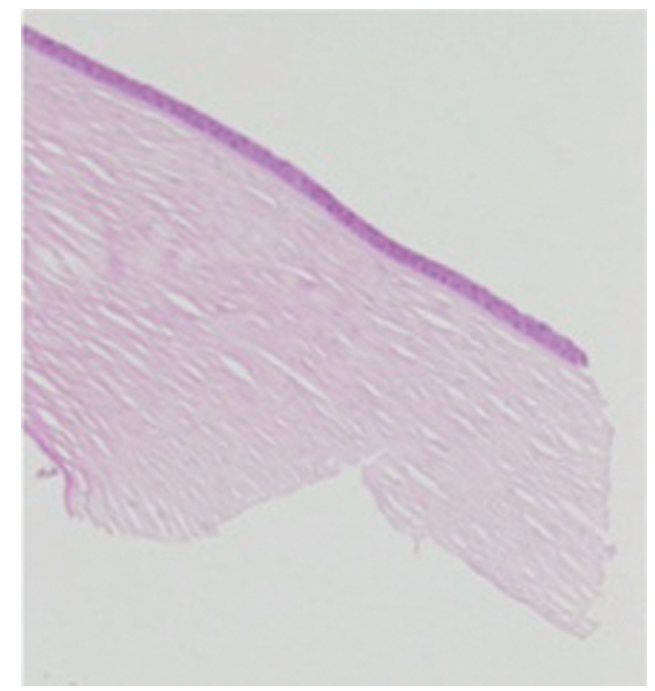

Figure 4 Light microscopy of the donor corneal rim (hematoxylin and eosin, 40×), demonstrating precise incision by the femtosecond laser, with minimal disruption to the surrounding architecture.
Femtosecond laser can make precise cuts in the cornea. Customized shaped incisions employed in corneal transplantation that were technically challenging with manual dissection in the past can now be performed easily with femtosecond laser. Such an application of the femtosecond laser in penetrating keratoplasty potentially reduces many problems encountered postoperatively, such as graft-host misalignment and astigmatism.

In our series of 10 eyes that had undergone FLPK with the femtosecond laser, we have demonstrated good visual and refractive outcomes as early as the third postoperative month. This is similar to or even better than the results of many other reported studies with FLPK. At 3 months postoperatively, we reported a mean manifest refractive and topographic cylinder of $2.31 \pm 1.41 \mathrm{D}$ and $2.59 \pm 1.57 \mathrm{D}$, respectively. Patient 1 , who had interrupted sutures with a very high cylinder of $12 \mathrm{D}$ at 3 months, was excluded from the analysis at postoperative month 3 . Bahar et al reported a lower mean cylinder with IntraLase-enabled penetrating keratoplasty $(3.6 \pm 1.9 \mathrm{D})$ compared with top-hat penetrating keratoplasty using manual dissection $(5.1 \pm 3.2 \mathrm{D})$ at one year. ${ }^{8}$ Price et al used a top-hat configuration in their series of six eyes, and achieved postoperative cylinder of $2.25 \mathrm{D}$ to 8 D. ${ }^{9}$ A series of seven eyes with top-hat configuration reported by Buratto and Bohm also achieved cylinder ranging from $2 \mathrm{D}$ to $3 \mathrm{D}$, except for one eye with $5 \mathrm{D}$ of cylinder. ${ }^{10}$ Chamberlain et al showed that using a continuous suturing technique in femtosecond laser-assisted keratoplasty produced less than $2.9 \mathrm{D}$ of cylinder in nine of 13 patients by postoperative month $3 .{ }^{11}$ Filatov et al also showed a mean keratometric astigmatism of $3.0 \pm 2.4 \mathrm{D}$ at postoperative month 6 with similar 24-bite running sutures. ${ }^{12}$ Coupled with precise graft-host wound matching, continuous suturing allowed for even distribution of tension throughout the wound and hence better astigmatic control. Four eyes in our series had placement of interrupted sutures. Patient 1 who had interrupted sutures, showed high astigmatism of $12 \mathrm{D}$ at postoperative month 3 , but such high astigmatism was not encountered in the other three eyes with interrupted sutures. Although a very small number of eyes, interrupted sutures did not seem to affect the astigmatic outcomes.

Williams et $\mathrm{al}^{13}$ and Panda et $\mathrm{al}^{14}$ respectively reported that up to $38 \%$ and five of 24 eyes with conventional penetrating keratoplasty had astigmatism of more than $5 \mathrm{D}$. In a recent American Academy of Ophthalmology report comparing deep anterior lamellar keratoplasty with conventional penetrating keratoplasty, Reinhart et a ${ }^{15}$ cited 11 studies which included a direct comparison of these two techniques, and 
six reported mean astigmatism from penetrating keratoplasty ranging from $1.5 \mathrm{D}$ to $5 \mathrm{D}$, with four studies citing more than $3.2 \mathrm{D}$ of cylinder. We demonstrated a lower mean manifest refractive cylinder at 3 months after surgery. While conventional penetrating keratoplasty may result in similar astigmatism, it usually took a year or longer to achieve. With precise wound-matching, FLPK seemed to achieve a lower astigmatism value within a much shorter period of time, and aided in rapid visual rehabilitation.

Spectral domain anterior segment OCT demonstrated excellent wound matching and apposition created by shaped incisions between the donor and recipient corneas. The interlocking edges in these shaped profiles conferred greater stability and less graft mobility and torsion. Together with a larger wound surface area, this resulted in greater wound adhesion and strength. ${ }^{11}$ Improved alignment of the edges facilitates faster wound healing and potentially enables suture removal as early as 3-6 months..$^{8,10,11}$ Therefore, more rapid visual rehabilitation could be achieved. On histopathological sectioning (Figure 4), the cut edges were noted to be smooth with no damage to adjacent collagen fibers or keratocyte nuclei.

Our study showed a mean reduction in endothelial cell density of $20.7 \%$, which is better than the reported $27 \%-40 \%$ loss one year after penetrating keratoplasty for low-risk grafts $^{16,17}$ based on the Brightbill classification. Kim et al reported endothelial cell loss of between $4.80 \%$ and $5.38 \%$ in their porcine model. ${ }^{18}$ Price et $\mathrm{al}^{9}$ and Buratto and Bohm ${ }^{10}$ showed excellent endothelial cell density of more than 2000 cells $/ \mathrm{mm}^{2}$ at 3 months and one year after FLPK. Less loss of endothelial cell density could be due to the larger posterior corneal surface that was transplanted. However, a study reported by Bahar et $\mathrm{al}^{8}$ demonstrated an endothelial cell density loss of $32.4 \%$ after intraLase-enabled penetrating keratoplasty. These authors postulated that femtosecond laser energy could induce damage to endothelial cells during the incision. Hoffart et $\mathrm{al}^{19}$ suggested that the $39.7 \%$ reduction in endothelial cell density from the preoperative count in their series could have resulted from manipulation of the donor tissue over the artificial anterior chamber and uncontrolled "intraocular" pressure rise during corneal applanation. However, this needs to be evaluated further. In this series, the low endothelial cell density loss could reflect our meticulous and cautious protection of the donor endothelium surfaces by coating them with copious amounts of ophthalmic viscoelastic device prior to mounting onto the artificial anterior chamber, and filling the anterior chambers with ophthalmic viscoelastic device coating during surgery to avoid any inadvertent chamber collapse and resulting endothelial cell damage.

The limitations of this study included its retrospective nature, small sample size, short follow-up period, and lack of a control group. Further large prospective series comparing FLPK with conventional penetrating keratoplasty could further validate the benefits of FLPK. There were no cases of rejection or primary graft failure in our series.

In summary, the outcome of this series of 10 eyes supports the benefits and safety of FLPK in terms of less postoperative corneal astigmatism within the early postoperative period, a good visual outcome with earlier visual rehabilitation, and minimal endothelial cell loss over a one-year period.

\section{Disclosure}

The authors report no conflicts of interest in this work.

\section{References}

1. Perlman EM. An analysis and interpretation of refractive errors after penetrating keratoplasty. Ophthalmology. 1981;88:39-45.

2. Barraquer J, Rutllan J, editors. Microsurgery of the Cornea, An Atlas and Textbook. Barcelona, Spain: Ediciones Scriba; 1984.

3. Busin M. A new lamellar wound configuration for penetrating keratoplasty. Arch Ophthalmol. 2003;121:260-265.

4. Ignacio TS, Nguyen TB, Chuck RS, et al. Top hat wound configuration for penetrating keratoplasty using the femtosecond laser: a laboratory model. Cornea. 2006;25:336-340.

5. Bahar I, Kaiserman I, McAllum P, et al. Femtosecond laser-assisted penetrating keratoplasty: stability evaluation of different wound configurations. Cornea. 2008;27:209-211.

6. Steinert RF, Ignacio TS, Sarayba MA. "Top hat"-shaped penetrating keratoplasty using the femtosecond laser. Am J Ophthalmol. 2007;143:689-691.

7. Kook D, Derhartunian V, Bug R, et al. Top-hat shaped corneal trephination for penetrating keratoplasty using the femtosecond laser: a histomorphological study. Cornea. 2009;28:795-800.

8. Bahar I, Kaiserman I, Lange AP, et al. Femtosecond laser versus manual dissection for top hat penetrating keratoplasty. $\mathrm{Br}$ J Ophthalmol. 2009;93:73-78.

9. Price FW Jr, Price MO. Femtosecond laser shaped penetrating keratoplasty: one-year results utilizing a top-hat configuration. $\mathrm{Am} \mathrm{J}$ Ophthalmol. 2008;145:210-214.

10. Buratto L, Bohm E. The use of the femtosecond laser in penetrating keratoplasty. Am J Ophthalmol. 2007;143:737-742.

11. Chamberlain WD, Rush SW, Mathers WD, et al. Comparison of femtosecond laser-assisted keratoplasty versus conventional penetrating keratoplasty. Ophthalmology. 2011;118:486-491.

12. Filatov V, Steinert RF, Talamo JH. Postkeratoplasty astigmatism with single running suture or interrupted sutures. Am J Ophthalmol. 1993;115:715-721.

13. Williams KA, Ash JK, Pararajasegaram P, Harris S, Coster DJ. Longterm outcome after corneal transplantation. Visual result and patient perception of success. Ophthalmology. 1991;98:651-677.

14. Panda A, Bageshwar LM, Ray M, Singh JP, Kumar A. Deep lamellar keratoplasty versus penetrating keratoplasty for corneal lesions. Cornea. 1999;18:172-175.

15. Reinhart WJ, Musch DC, Jacobs DS, Lee WB, Kaufman SC, Shtein RM. Deep anterior lamellar keratoplasty as an alternative to penetrating keratoplasty: a report by the American Academy of Ophthalmology. Ophthalmology. 2011;118:209-218. 
16. Cheng YY, Visser N, Schouten JS, et al. Endothelial cell loss and visual outcome of deep anterior lamellar keratoplasty versus penetrating keratoplasty: a randomized multicenter clinical trial. Ophthalmology. 2011;118:302-309.

17. Ang M, Mehta JS, Anshu A, et al. Endothelial cell counts after Descemet's stripping automated endothelial keratoplasty versus penetrating keratoplasty in Asian eyes. Clin Ophthalmol. 2012;6: 537-544.
18. Kim JH, Choi SK, Lee D. The comparison of femtosecond laserassisted penetrating keratoplasty with conventional surgery in terms of endothelial safety: ex vivo study using porcine eyes. Cornea. 2009;28: 812-816.

19. Hoffart L, Proust H, Matonti F, et al. Short-term results of penetrating keratoplasty performed with the femtec femtosecond laser. $A m J$ Ophthalmol. 2008;146:50-55.

\section{Publish your work in this journal}

Clinical Ophthalmology is an international, peer-reviewed journal covering all subspecialties within ophthalmology. Key topics include: Optometry; Visual science; Pharmacology and drug therapy in eye diseases; Basic Sciences; Primary and Secondary eye care; Patien Safety and Quality of Care Improvements. This journal is indexed on

Submit your manuscript here: http://www.dovepress.com/clinical-ophthalmology-journal

\section{Dovepress}

PubMed Central and CAS, and is the official journal of The Society of Clinical Ophthalmology (SCO). The manuscript management system is completely online and includes a very quick and fair peer-review system, which is all easy to use. Visit http://www.dovepress.com/ testimonials.php to read real quotes from published authors. 